JELTL (Journal of English Language Teaching and Linguistics) e-ISSN: 2502-6062, p-ISSN: 2503-1848

2019, Vol. 4(3)

www.jeltl.org

\title{
Cross-Cultural Communication: Communication Accommodation Experiences of Pattani Students with Javanese Students at IAIN Tulungagung
}

\author{
Mohamad Jazeri \\ Institut Agama Islam Negeri (IAIN) Tulungagung, Indonesia \\ e-mail: mohamadjazeri69@gmail.com \\ Dwi Astuti Wahyu Nurhayati \\ Institut Agama Islam Negeri (IAIN) Tulungagung, Indonesia \\ e-mail:dwiastuti507@gmail.com
}

\begin{abstract}
Cultural differences between native and Indonesian culture makes foreign students in Indonesia experience a culture shock. Such case occurs on students from Pattani, South Thailand, who study in IAIN Tulungagung. To overcome that culture shock, Pattani students do communication accommodation to make them feel comfortable in a new environment, and thus can be accepted by Javanese students from Indonesia. This research was a kind of qualitative study. The data were collected by using observation and interview techniques. To find out the forms of communication accommodation performed by Pattani students, the researchers adopted communication accommodation theory by Giles. The results of this research revealed that there were two forms of communication accommodation performed by Pattani student. Firstly, convergence, was performed when Pattani students tried to level communication behavior with their speech partners. Convergence done by Pattani students can be classified into pre-convergence, convergence process, and post convergence. Secondly, divergence is defending Pattani identity when communicating with Javanese students. Divergence accommodation was performed in two forms namely verbal and nonverbal.
\end{abstract}

Keywords: accommodation, communication, convergence, divergence

JELTL (Journal of English Language Teaching and Linguistics), 4(3), 2019 


\section{INTRODUCTION}

The more advanced human civilization, the wider intercourse mobility humans experience. At this time, cultural and language contacts occur as a cross cultural communication. Cross cultural communication happens when individuals from a particular culture deliver a message that must be understood by individuals from another culture (Muchtar, Koswara, \& Setiaman, 2019). The arrival of Pattani students, South Thailand, in IAIN Tulungagung is an example of cross-cultural communication. The more identical the cultures among communicators, the easier the communication process occur. However, the bigger the cultural difference among communicators, the harder the communication process runs effectively.

In order that cross cultural communication runs effectively and does not cause any misunderstanding, communication accommodation needs to be performed. Accommodation is referred to as a social process that has two meanings; firstly, it is a social process that shows a balanced condition in social interaction among individuals and groups in a society, mainly in terms of norms and social values approved in that society. Secondly, it refers an ongoing process, in which accommodation shows a process to assuage contradiction in a society including norms and values existing in that society. The goal of accommodation process is to achieve stability (Sentosa, 2015). Then instead of the term of accommodation or adaptation problems, subsequent studies revealed that the anxieties associated with immersing oneself in the social environment of the local culture led many sojourners to form enclaves of fellow nationals that largely determined their living arrangements, friendship patterns, and organizational affiliations. Such enclaves allowed the sojourner to re-establish primary group relations and maintain familiar, traditional values, and belief systems while minimizing psychological and behavioural adaptation. A protective function was served whereby psychological security, self-esteem, and a sense of belonging were provided while anxiety, feelings of powerlessness and social stresses were reduced (Mastor et. al., 2011; Nasirudeen, Josephine, Adeline, Seng, \& Ling, 2014). Seeing all those situations and problems of Pattani students could be portrayed using communication convergence.

The other previous studies related communication were conducted by some researchers (Lukyanova, Daneykin, \& Daneikina, 2015) who observed that communication competence is a prerequisite for the successful development or it is such kind of a demonstrated area of successful communication activity on the basis of acquired tools and strategies of verbal communication supported by linguistic and language skills. Communication accommodation firstly emerged in the beginning of 70 s that basically focused on the willingness of communicators from different cultures and language to adapt to each other in order that the occurring communication runs effectively. In this case, communication accommodation theory is adopted to explain sociolinguistics phenomenon. Accommodation process assists language skill of foreign students or immigrants to be accepted by host society (Giles, Coupland, \& Coupland, 2010).

Some previous studies found that Indonesian students have faced difficulties in adjusting themselves to life in foreign cultures, such as those who studied in Taiwan, and the United Kingdom (Aisha \& Mulyana, 2019). The most critical point of experience is repeatedly termed culture shock, a condition in which the individual feels anxious, 
uncomfortable, frustrated, and threatened when living in a new environment. Then another study conducted by Zhang (2014) who examined culture shock is one of the common experiences by the students abroad. Next study is still related to culture shock, it can be defined as a well-known term used to declare the initial experiences of immersion in an unfamiliar culture (Lombard, 2014).

Talking communication among foreign students does not only happen in Asia students but also concern to some aspects such as culture shock which is studied in linguistic, psychology, and anthropology. In this case, this current study attempted to investigate how communication accommodation or culture shock impacted on Thailand students to study in Tulungagung. A study also implemented by some other researchers (Qun, Syihabuddin, Mulyati, \& Damaianti, 2018) who concerned on Chinese Indonesian-language students intercultural communicative competence in the light of they are language major students. For example intercultural communication sometimes breaks down in real-life conversations. Another study also carried out by other researcher related to communicating among foreign students and teaching Islamic context. Communication accommodation was once done by Wali Sanga in teaching Islam to Nusantara people, at which Indonesia still had strong cultures influenced by Hindu and Buddha. Wali Sanga adapted Islamic teaching to local cultures to avoid rejection and conflict. With such a good communication accommodation with diverse cultures growing at that time, Islamization in Nusantara run peacefully without any conflicts (Syam, 2019).

The problem of communication accommodation has been examined by Roifah on her study about Communication Accommodation of Imakes in Cross Cultural Interaction" (A Descriptive Qualitative Study on Accommodation of Members of Student Association from Kebumen Living in Solo). Referring to the result of this research, it is known that communication accommodation in cross cultural interaction of students from Kebumen revealed language modifications when they initially interacted with other students. Firstly, they did not show their native cultural identity since they were afraid of being not understood when using Ngapak dialect. IMAKES students' tent to observe and learn the situation before joining and taking risks, then they decided what kind of appropriate responses to any situations. With such accommodation, Kebumen students did not encounter any obstacles.

Another research on communication accommodation has been carried out by Safril (2016) on Pattani students in UIN Sunan Gunung Jati, Bandung. This research aims at investigating culture shock experienced by Pattani students as well as communication accommodation process they performed. Using phenomenology design, this research found out those Pattani students in UIN Sunan Gunung Jati encountered culture shock in two aspects namely psychology and social. To overcome the culture shock, Pattani students performed convergence and divergence communication accommodation either verbally or non-verbally (Safril, 2016).

The other relevant studies on international students 'language and cross-cultural adaptation and dominant language in Taiwan (Chang, 2011), this study focused on the communication accommodation, relationship between the linguistic competence acquired from studying abroad and the level of cross-cultural adaptation, as well as how they affect each other. There is also study conducted (Supianoski, 2012) on the cross cultural 


\section{Mohamad Jazeri \& Dwi Astuti Wahyu Nurhayati}

interactions of international students in college. This study was conducted on the campus of Midwestern by giving questionnaire and conducting interview. The results of the study indicated that cross cultural interaction of international students often occur, and cross cultural interactions affected students academically, socially, and psychologically.

This research aims at describing and elaborating the forms of communication accommodation performed by Pattani students in IAIN Tulungagung. This research is comparable to Safril (2016) exploring communication accommodation done by Pattani students in UIN Sunan Gunung Jati, Bandung, yet it is novel since Pattani students in Bandung interacted with Sundanese culture, while Pattani students in Tulungagung interacted with Javenese culture. Such cultural difference surely makes their communication accommodation different.

\section{LITERATURE REVIEW}

Communication Accommodation Theory (CAT) provides a wide-ranging framework aimed at predicting and explaining many of the adjustment individuals make to create, maintain, or decrease social distance in interaction (Giles \& Ogay, 2007). It explores the different ways in which we accommodate our communication, our motivations for doing so, and the consequence. CAT addresses interpersonal communication issues, yet also links it with the larger context of the intergroup stakes of an encounter. In other words, sometimes our communications are driven by our personal identities as speaker or hearer. Communication accommodation is a sociolinguistics phenomenon of the willingness of communicators from different cultures and language to adapt to each other in order that the occurring communication runs effectively. It firstly emerged in the beginning of 70s when people from different cultures and languages met and get together in the same place. In order to be able to communicate to each other they should accommodate the way they usually use, basically the language and culture. In this case, communication accommodation theory is adopted to explain accommodation process assists language skill of foreign students or immigrants to be accepted by host society (Giles, Coupland, \& Coupland, 2010).

Giles et al. explained the accommodation theory is presented as a basis for sociolinguistic explanation, and it is concerned with motivations underlying the willingness of adapting our language and communication patterns toward others. It is also concerned with consequences arising from the accommodation process. For language learners or immigrants, accommodative processes can, for example, facilitate or impede them to be accepted by certain host communities; affect audience ratings; affect reaction to defendants in court; and be an enabling handicapped people to fulfill their communicative potential (Giles et. al., 2010). Speech accommodation theory is a profitable framework for elucidating the sociolinguistic mechanics of, and the social psychological processes underlying, intergenerational encounters (Coupland, Coupland, Giles, \& Henwood, 1988).

\section{RESEARCH METHODS}

This research was a descriptive qualitative study focusing on cross cultural communication. The subjects in this study were students of IAIN Tulungagung who come from Pattani, Thailand, and students originate in Java, particularly East Java. The subjects 
participating in this study were students who had different languages and lived in different cultures; Pattani (Malay) and Java (Javanese). The respondents of study are two Javanese students and eight Pattani's students. The two Javanese students are Zen Rozan and Nurul. While eingt Pattani's students are Hadi Nuyeim, Najwa, Ulaiyah, Nooresa, Wan Ahmad, Abdurohman Chelong, and Kholiyoh Bueraheng. The data in this study were efforts of either verbal or non-verbal communication accommodation done by Pattani and Javanese students in IAIN Tulungagung. The data were collected by using participant observation and interview. Participant observation is direct involvement of the researchers in communication accommodation that played an important role in guiding foreign students in IAIN Tulungagung. The data were analyzed by using flow model interactively that consisted of data collection, data reduction, data display, verification, and final conclusion (Miles \& Huberman, 2014). Data reduction and data display were conducted by referring to communication accommodation theory (Giles et al, 2010).

\section{FINDINGS}

The data collected through observation, documentation and interview were analyzed based on the classification of the objectives of this study. The data classification is based on communication accommodation theory. The result of this study revealed that Pattani students performed convergence and divergence communication accommodation. There are some stages that they have to face. Convergence Communication Accommodation, convergence is a cultural adaptation of individuals to a new culture or society (Giles et al., 2010). Convergence is classified into three stages, namely pre-convergence, convergence process, and post convergence.

Based on the result of observation, it can be said that most of Thai students conduct convergence communication accommodation in some ways. The first phase is honeymoon contact, optimistic phase, euphoria. In this phase occurs when the student experiences interesting situation for example introducing to others, euphoria (be happy with the environment, fascinating events (joining the PBAK) with new culture and new people he or she encounters. Every activity looks very pleasant, such as the food pecel, the Javanese people, Indonesian and Javanese, the facilities (Living in Mahad), the hot weather, Tulungagung area, and the arts (Tari Reog Kendang). Next, feeling happy and hopeful is also present in the beginning, and this stage usually lasts only few weeks after the person arrives in Indonesia especially Tulungagung, East Java. This finding is in line with

On that occasion, pertaining to the result of documentation, in the convergence stage, they got some troubles or crisis (disintegration, cultural problems, disillusionment, frustration Pattani students feel disappointed if they could manage the task, dissatisfied with the communication conducted in the process of teaching learning, desperate with the communication when they are asked or given task by the lecturer, especially they could not understand what the lecturers instruct to them. This phase describes the situation when a person finds the differences between his or her culture and other cultures. These differences create problems that may lead to the worst is point of this phase, that is, culture shock. Moreover, it raises an aggressive attitude and hostility due to the difficulty to adapt, homesickness, boredom, changing mood, sensitivity and feeling isolated from the rest of the society. On the other hand, the host people do not ignore the foreigner that may create more 
resistance toward them. According to Dodd as cited in Samovar et al., (2006), the crisis phase is often characterized by feelings of disappointed, dissatisfaction, as if everything looks horrible. It is also in line with another study conducted by Guinapa as cited in Qun et al., (2018) who examined that one of the problems faced by the foreign students is culture shock which can be defined as the physical and emotional discomfort one suffers when coming to live in another country or a place different from the place of origin. In this case, it represents the lack of direction the feeling of not knowing what to do or how to do things in a new environment, and snot knowing what is appropriate or inappropriate.

Afterward from the interviews 'result, in pre-convergence stage, it can be restated that Pattani students introduced themselves to their classmates, Indonesian students. At this stage, to adapt to each other, they asked about words used in self-introduction and memorized the words. Either Pattani or Indonesian students learned each other and memorized expressions commonly used in daily communication such as "Apa kabar?" [How are you?]," Siapa namamu" [What is your name?], or "Dari mana asalmu" [Where do you come from?] . Indonesian students also asked the meaning of those expressions in Malay language and Thai language. Since both Pattani and Indonesian students are bilingual, they also learned two languages at once. Pattani students learned Indonesian and Javanese language, whereas Indonesian students learned Malay and Thai language. The researchers found out that Pattani students counted in Javanese language, and Indonesian students counted in Thai language. The followings are the result of interview with Hadi Nuyeim and Zen Rozan.

[1] ..."saya senang di sini karena bias belajar Bahasa Indonesia dan Jawa. Saya sudah biasa berhitung satu sampai sepuluh dalam Bahasa Jawa. Siji, loro, telu, e papat, e lima, nenem, pitu, wolu, sanga, terus e sepuluh. "[I am so excited here because I can learn Indonesian and Javanese language. I can count from one to ten in Javanese. One, two, three, four, five, six, seven, eight, nine, ten.] (This interview was conducted with Hadi Nuyeim, a Pattani student).

[2] "Saya berkenalan dengan teman dari Pattani Namanya Hadi Nuyeim. Dia banyak bertanya tentang Bahasa Jawa. Akhirnya saya jga belajar Bahasa Thai. Saya sudah bias berhitung sampai sepuluh. Bulan Mei nanti saya akan ke Thailand untuk KKN di sana. Agar di sana nanti tidak bingung, saya juga banyak bertanya tentang kebiasaan orang sana." [I met a new friend from Pattani named Hadi Nuyeim. He asked a lot about Javanese language. Finally, I also learn Thai language. I can count up to ten. Later in May I will go to Thailand to do community service there. To make sure I was not confused, I ask a lot about people's custom there.] (An Interview is conducted to Zen Rozan, an Indonesian student and a participant of Thailand Community Service).

In addition to language, Pattani students must adapt to kinds of food which are usually eaten by Javanese students. Pattani students used to have breakfast with nasi kerapu, whereas what is available in canteen for breakfast is usually nasi pecel. They were initially puzzled since there was only nasi pecel. However, Pattani students slowly started to enjoy having breakfast with it. Likewise, Javanese students could not enjoy meals served by 
Pattani students. The following data are the result of interview with Najwa (Pattani student), and Nurul (Javanese student).

[3] Saya diajak ke kantin kampus oleh teman Indonesia, saya bingung makan apa, kerena makanan di sini saya tidak suka. Saya tidak bisa (suka) makan tempe dan tahu. Tapi lama-lama saya suka makan tempe. [I once was invited by Indonesian friends to eat in the campus canteen, yet I did not know what to eat since I do not like meals here. I cannot like or eat tempeh and tofu. However, I slowly like to eat tempeh.] (an interview with Najwa).

Saya pernah ke kos Najwa, saya diberi makan tom yam, tapi rasanya pedas dan asem sekali. Saya hanya makan sedikit. Takut sakit perut. [I once went to Najwa's boarding house, and she served me with tom yam, yet it tasted so spicy and sour. I was afraid of getting stomachache.] (an interview with Nurul).

Communication accommodation in pre-convergence stage is a positive convergence, that is, to replicate and adapt to the manner of talking, and to like the same food. Pattani students learned to memorize Indonesian and Javanese language, while Indonesian students learned Malay and Thai language.

In process stage, Pattani students did communication accommodation by following BIPA (Indonesian Language for Foreign Speaker) course, held by the campus for about three months. To get along with Javanese students, Pattani students learned non-standard Indonesian, while in BIPA class they learned standard language to prepare for studying and writing paper. The following is the result of interview with Ulaiyah who is commonly known as Layin.

[4] Untuk bisa berbahasa Indonesia dengan cepat, kami mengikuti pelajaran Bahasa Indonesia yang diasuh bapak Jazeri. Kita diajak mengenal Indonesia dengan rihlah ke pantai Prigi. [To be able to speak Indonesian, we follow Indonesian language lesson taught by Mr. Jazeri. He introduced Indonesian language to us by doing rihlah to Prigi beach.] (Interview with Layin).

In addition to following BIPA, Pattani students also joined extracurricular activities such as Students Association (HMJ), Students Mountaineering Club (MAPALA), and Futsal. Hamdan and Abdul Rahman joined Futsal, while Laila da Nooresa joined Students Mountaineering Club. The following is Nooresa's response:

[5] Teman-teman banyak yang ikut organiasi kampus. Hamdan dan Abdul Rahman ikut futsal, Abidah dan Haifa ikut PMR, saya dan Laila ikut MAPALA. Saya senang bias jalan-jalan, naik gunung. [Most of my friends joined campus organizations. Hamdan and Abdul Rahman joined Futsal, Abidah and Haifa joined Youth Red Cross (PMR), while Laila and I joined Students Mountaineering Club. I love hiking the mountain.] (Interview with Nooresa). 


\section{Mohamad Jazeri \& Dwi Astuti Wahyu Nurhayati}

In post convergence stage, Pattani students were courageous to get involved in Indonesian students 'activities such as playing futsal, hiking the mountain, and etc. Their skill in Indonesian language also improved. Some of them did not feel at home and then they returned, but some of them never got home although they had holidays. In communication, both Pattani and Indonesian students used Indonesian language; Javanese students no longer used Javanese language. The following data is worth attention.

[6] Saya sudah dua tahun di sini. Masa-masa awal memang ada kusulitan berkomunikasi dengan teman-teman Indonesia. Sekarang teman Indonesia saya banyak. Mahasiswa Pattani sering diajak main bola, naik gunung, dan jalan wisata ke pantai Gemah. Setiap tahun mahasiswa Pattani bertambah sampai sekarang sekitar seratus lebih. Saya merasa seperti di kampung sendiri. [I have been here for two years. The beginning was difficult especially to communicate with Indonesian friends. Now I have a lot of Indonesian friends. In each year, the number of Pattani students increase; there are about more than one hundred students. Pattani students are often invited to play football, hike the mountain, or just take vacation in Gemah beach. I feel at home.] (An interview is conducted to Laila Salaeh).

Communication accommodation done by Pattani students is consistent with communication accommodation theory by Giles et al. In this stage, they kept doing adaptation by using the same language. They felt comfortable getting along with each other since they tried to use the same language, namely Indonesian language (Coupland \& Giles, 1988; Howard Giles dkk., 2010; White, Giles, Coupland, \& Coupland, 1993).

Divergence is individuals 'way to communicate by doing self-adaptation, yet still keeping their identity (Giles et al., 2010). Divergence done by Pattani students in IAIN Tulungagung is classified into two categories: verbal divergence and non-verbal divergence.

Verbal divergence was performed by using Thai and Malay language in the process of communication among Pattani students. This verbal divergence was identifiable when Pattani students communicated with their friends who lived in the same house. There were 17 houses rent for Pattani students. Each house was inhabited by 8-10 students, depending on the size of the house. There was a big house that was inhabited by twenty students. They uncovered that living in one house made them feel comfortable and calm. They could cook meals they like, and they could keep their intercourse that they think more represented Islam.

When they first came to Indonesia, they spoke Malay and Thai language. Although Malay language has much in common with Indonesian language, Pattani students 'language was not easily understood by Indonesian students. Malay language of Pattani students is much influenced by Thai language, so it sounds extremely different from Indonesian language. The followings are the comparison of Malay language and Indonesian language.

$\begin{array}{lll}\text { Gi ma na? } & \text { Pergi ke mana? } & \text { Where are you going? } \\ \text { Pehe tak? } & \text { Paham gak? } & \text { Do you understand? } \\ \text { Make ike } & \text { Makan ikan } & \text { Eating fish }\end{array}$


With such differences, Javanese students encountered difficulties in understanding Malay language spoken by Pattani students. To overcome that problem, Javanese students asked to slow down the tempo of Pattani students 'speech, and to repeat their utterances. Likewise, Pattani students often asked Javanese students to repeat their utterances and explain the meaning.

Non-verbal divergence done by Pattani students can be categorized into three things: food, clothes, and cross-gender intercourse. In those three things, Pattani students thought they had to keep their identity.

Food is one of the factors that make newcomers miss their hometown. Indonesian students who were placed in Songkla, Thailand, often got healed of their yearning to Indonesia when the consulate served them with some lunch menus such as sayur asam, sambal terasi, and ikan asin. Pattani students in Tulungagung also felt at home when they ate nasi kerapu or tomyam. The following is the result of interview with Pattani students who was in charge of cooking.

[7] Teman-teman tidak bisa makan makanan Indonesia, kami masak sendiri di rumah kontrakan secara bergilir. Kami masak tomyam, som tam, kensum yang biasa kami makan di Pattani. Kami merasa di rumah. Selain itu, kami lebih hemat. [Our friends cannot eat Indonesian foods, so we cook our foods in the boarding house in turn. We cook tomyam, som tam, and kensum that we used to eat in Pattani. We feel at home. Besides, we can save money.] (Interview with Wan Ahmad).

In addition, Pattani students did divergence by defending their Muslim women identity of Pattani. Muslim women put on clothes that cover almost all of their body. Some of the students also wear veil. They do not wear pants like other Muslim women in Tulungagung. This finding corresponds to the result of interview with one of the boards of Pattani students in Tulungagung.

[8] Kami merasa perlu mempertahankan budaya pakaian kami. Kami punya aturan Senin memakai baju seragam organisasi (baju kurung berbahan batik khas Tulungagung). Selain itu kami yang perempuan memakai baju kurung dengan atasan sampai di bawah lutut dan jilbab lebih lebar. Teman Indonesia bilang jilbab syar'i. Bagi perempuan tidak boleh pakai celana, kecuali saat olah raga memakai celana olah raga. [We think we need to defend our fashion culture. We set rules that on Monday students must wear typical organization uniform (sack dress made of Batik from Tulungagung). Besides, women wear sack dress that covered almost all of their body, and they must wear wider veil. Indonesian friends call it syar' $i$ veil. Women are not allowed to wear pants, except when they have to do sports.] (An interview with Siti Kholiyoh Bueraheng).

Pattani studens and Tulungagung society actually have similarities in terms of religion, that is, most of the people are Muslim. However, they have different fashion culture. Many Muslim women in Indonesia do not wear veil. When they wear it, the veil is small and it does not cover chest and hip. Meanwhile, Muslim women in Pattani must wear veil. They 


\section{Mohamad Jazeri \& Dwi Astuti Wahyu Nurhayati}

wear long sack dress covering their body until knee, and they wear wider veil, too. Based on observation by looking at either Pattani students in Indonesia or Muslim women in Pattani, the researchers found the same phenomenon, that is, they wear syar'i clothes.

In social realm, there is a difference on intercourse culture between Pattani students and Javanese students. Indonesian students (Javanese) are accustomed to befriend with men and women. Some of them (man and woman) date and ride motorcycle together. In Pattani, such intercourse is prohibited. The following is the result of interview with the chief of Pattani Student Association in Indonesia (HMPI) in Tulungagung.

[9] Kami mencari rumah bersama karena kami merasa tenang. Kami bisa masak masakan Thailand karena kami tidak bisa makan masakan Indonesia. Kami juga menjaga adik-adik agar tidak bergaul seperti mahasiswa Indonesia. Mahasiwa Indonesia pacaran boncengan laki-laki dengan perempuan. Di Pattani itu tidak bisa (boleh). [We looked for a house to live together as we feel comfortable. We can cook Thailand foods since we cannot eat Indonesian foods. Indonesian students date and ride motorcycle together. It is prohibited in Pattani.] (An Interview with Abul Rahman Chelong, the chief of HMPI).

The different cross-gender intercourse culture in Pattani is relatively stricter rather than in Indonesia. They maintain their classic tradition that in Islam, men and women who are not muhrim are prohibited to get close to each other. Men and women are also not allowed to shake hands even with baboo (Islamic leader) or ustadz (Islamic teacher). This phenomenon was also found by the researchers when visiting Pattani several times.

\section{DISCUSSION}

This study revealed that Pattani students performed convergence and divergence communication accommodation. Convergence communication takes place in some situations towards them. Convergence is a cultural adaptation of individuals to a new culture or society (Giles et al., 2010). Convergence is classified into three stages, namely pre-convergence, convergence process, and post convergence. In pre-convergence stage, Pattani students introduced themselves to their classmates, Indonesian students. In process stage, Pattani students joint BIPA (Indonesian Language for Foreign Speaker) course, held by the campus for about three months. In post convergence stage, Pattani students involved in Indonesian students 'activities such as playing futsal, hiking the mountain, etc. This finding is consistent with Safril's finding concerning communication accommodation done by Pattani students in UIN Sunan Gunung Jati, Bandung. Safril figured out that in the early stage, the students performed communication accommodation with Sundanese students by memorizing expressions commonly used by Sundanese students (Safril, 2016). As a matter of fact, previous research has suggested that communicating with same culture members is minimally helpful intercultural adjustment (Lin, 2006). Related to the case of Pattani students as participants need to remain an open heart to foreign cultures and build multicultural competence in order to survive in the age of globalization (Syihabuddin, 2014). 
In this case, the Pattani students could be considered to get some stages of the cross culture adaptation in Indonesia as stated before. Those stages can be explored into a fourstage model of cross-cultural adjustment consisting of the phases of honeymoon, crisis, recovery and adjustment. This finding is similar with the study conducted by other researchers, Mulyana \& Eka (2017) who found that using U-curve model of cross-cultural adaption to portrait Indonesian students' efforts to adjust living in other country. As a matter of fact, in the context of the respondents 'experiences, these situations were characterized by the main barriers that include language and values of friendship, crosscultural stereotypes and prejudices that led to discrimination. Instead of that matter, it also identified culture shock faced by them as well their coping strategies to maintain their communication.

Based on the interview result and participant observations, most of the Pattani students got stressed culture shock symptoms and the influence in respect to intercultural communicative competence, especially for linguistics or content courses, or other subjects for example English Phonology, Introduction to Linguistics, Practical English Grammar. Some of them get difficulties to join the class and conduct communication by using English. In fact some of them got confused to understand the lexical terms and participate in classroom discussion. It is also in line with the study conducted by some other researchers (Qun et al., 2018) who examined the foreign students in perceiving and dealing the culture shock. Then it is believed and has been researched that by emerging oneself in environment, students will need to learn about the behavioral style and beliefs of local people, and also acquire the social skills of the host culture (Rinehart, 2002; Yang, Webster, \& Prosser, 2011).

In addition to convergence communication accommodation, Pattani students also used divergence communication accommodation. Divergence done by Pattani students in IAIN Tulungagung is classified into two categories: verbal divergence and non-verbal divergence. This finding is in line with intercultural communication, a student may know the literal meaning of an utterance, but fail to understand its contextual meaning, or fail to accurately understand the speaker's intended force, which is particularly normal and unavoidable in Asian culture (Huang, 2014). This finding also supports to Giles definition of divergence communication. Giles said that divergence is individuals 'way to communicate by doing self-adaptation, yet still keeping their identity (Giles et al., 2010). The similar finding to this research was found by Safril in investigating communication accommodation of Pattani students in UIN Sunan Gunung Jati, Bandung (Safril, 2016). Not to mention, the similar finding was also found by Yohana \& Yozani in their study on the process of communication accommodation performed by illegal immigrants from Afghanistan in Pekanbaru (Yohana \& Yozani, 2017). Divergence performed by Pattani students was similar to what immigrants from Afghanistan did in Pekanbaru, Riau (Yohana \& Yozani, 2017). Besides, the same thing was visible in divergence done by Pattani students in UIN Sunan Gunung Jati, Bandung. They hold that identity since they have to do their obligation as a Muslim (Safril, 2016). 


\section{CONCLUSION}

Communication accommodation between Pattani students and Javanese students in IAIN Tulungagung was done in two forms namely convergence accommodation and divergence accommodation. Both occurred during the communication process between Pattani students and Javanese students by putting aside their cultural attribute. Javanese students performed good communication accommodation since they mastered Indonesian language. Meanwhile, Pattani students less encountered difficulties in doing communication accommodation since they had not fully mastered Indonesian language yet, as the result they got some efforts to maintain the communication by using their facial expression and gestures (Howard Giles \& Ogay, 2007). As time goes by, Pattani students did convergence by memorizing Indonesian expressions, following BIPA course, and joining extracurricular activities in the campus such as Futsal, Students Mountaineering Club (MAPALA), Indonesian Red Cross, etc. Motivation underlying Pattani students in doing convergence accommodation was to be accepted in Javanese students' community.

However, to maintain self-identity, Pattani students also performed divergence accommodation, that is, by holding Muslim identity of Pattani. Divergence accommodation done by Pattani students was to live together in a house, therefore they could cook by themselves and saved money; to wear Muslim clothes of Pattani that they thought was more syar'i; and to keep their cross-gender relationship to avoid free sexual relationship.

It can be inferred that the Pattani students as one of international students language and cross-cultural adaptation concerning the dimension of local culture has the highest level among four dimensions that were found in this study related to Javanese as local language, traditional show, traditional food and getting along with together (Gayatri \& Andhini, 2016; H. Huang \& Yongsheng, 2011). The use of language plays role in this problem as well. Local students, IAIN Tulungagung pupils, usually use Javanese language in daily conversation, while Pattani students use Indonesian or Malay, Thailand, and English.

In this case, an important motive for convergence is the desire to gain approval from one another. The more similar we are to our conversational partner, the more he or she will like or respect us, and the more social rewards we expect. Converging to a common linguistic style also improves the effectiveness of communication, this, in turn, has been associated with the increased predictability of the other and hence a lowering of uncertainty, interpersonal anxiety, and mutual understanding (see, e.g. Gudykunts, 1995).

However, divergence can be also adopted in order to shaper receivers' attributions and feelings. Pattani students could purposely say some words in Thailand during the conversation, in order to remind her interactive partners that she does not belong to the same linguistic group. By doing so, she/he signals that her/his possibly unsubtle discourse should be attributed to her linguistic (in) competence rather than to deficient intellectual capacities. Divergence can also be attempting to entice an interlocutor to adopt a more effective communicative stance. Again referring to our example, if the student is talking loudly and very expressively, the lecturer may exhibit a divergent response (e.g., speaking softly and with a neutral affect) in order to encourage the student to adopt a more reserved and seemingly thoughtful style. Note also that a strategy of maintenance can not only result from insensitivity to others 'styles, it can also be a deliberate attempt to affirm one's identity or 
autonomy in a low-key fashion without emphasizing it. All in all, it appears that satisfying communication requires a delicate balance between convergence-to demonstrate willingness to communicate-and divergence-to incur a healthy sense of group identity (Cargile \& Giles, 1996).

Based on the findings, the researcher suggests that a self-restraint attitude should be built so that students can survive in a different and unfamiliar cultural environment as the result they may maintain any communication attempts. It is also suggested that teachers should encourage and support students to frequently engage in intercultural communions, and the educational institutions should provide peer support and develop certain media and methods on improving intercultural communicative competence to help students alleviate culture shock symptoms.

This study also showed that from the interviews that self- confidence, self-efficacy and self-motivation play key roles in decreasing anxiety and overcoming culture shock issues (Saylag, 2013). Students with high self- efficacy usually believe that they have abilities to perform tasks well. Lack of confidence is one of the most important reasons for failure. Although different people use various techniques to try to minimize the impact of culture shock, it seems that a high degree of self-confidence and optimism may be among the most effective.

This research, as most do, was conducted with a number of limitations. First, the interviews were done in Bahasa Indonesia then translated into English. Therefore, it is possible that the context meaning was not delivered intactly. Second, although highly unlikely, it remains a possibility that students who participated in the research were the only ones who had experienced culture shock in the research scope. It is suggested that further research might focus on teaching media and methods development or how to well prepare students who are going to study abroad both in culture and communication.

\section{REFERENCES}

Aisha, S., \& Mulyana, D. (2019). Indonesian postgraduate students' intercultural communication experiences in the United Kingdom. Jurnal Kajian Komunikasi, 7(1), 113. https://doi.org/10.24198/jkk.v7i1.20901

Cargile, A. C., \& Giles, H. (1996). Intercultural communication training: Review, critique, and a new theoretical framework (Gudykunts (Ed.), Communicative yearbook 19). Thousand Oaks, CA: SAGE Publications.

Chang, Y. (2011). The Relationship between International Students' Cross-Cultural Adaptation and Dominant Language in Taiwan. International Journal of Humanities and Social Science, 1(7).

Coupland, N., Coupland, J., Giles, H., \& Henwood, K. (1988). Accommodating the elderly: Invoking and extending a theory1. Language in Society. https://doi.org/10.1017/S0047404500012574

Coupland, N., \& Giles, H. (1988). Introduction the communicative contexts of accommodation. Language and Communication. https://doi.org/10.1016/02715309(88)90015-8

JELTL (Journal of English Language Teaching and Linguistics), 4(3), 2019 
Gayatri, M.N., \& Andhini, N.I. (2016). (2016). International students'cross-cultura;l and language adaptation in Indonesia (An Analysis of Turkish and Kyrgyz students of English Department at State University of Semarang). , 585-590. Sebelas Maret University. Dipresentasikan pada International Seminar Prasasti III: Current Research in Linguistics, Sebelas Maret University.

Giles, H, Coupland, J., \& Coupland, N. (2010). Accommodation theory: Communication, context, and consequence. In H. Giles, N. Coupland, \& Coupland (Eds.), Contexts of Accommodation: Developments in applied sociolinguistics. Diambil dari https://doi.org/10.1017/cbo9780511663673.001

Giles, Howard, Coupland, N., \& Coupland, J. (2010). Accommodation theory: Communication, context, and consequence. Dalam Contexts of Accommodation. https://doi.org/10.1017/cbo9780511663673.001

Giles, Howard, \& Ogay, T. (2007). Communication Accommodation Theory. Dalam Explaining communication: Contemporary theories and exemplars (hlm. 293-310). Mahwah, NJ, US: Lawrence Erlbaum Associates Publishers.

Gudykunts, W. B. (1995). Anxiety uncertainty management (AUM) theory: Current status. In R.L.Wiseman (Ed.), Intercultural communication theory. Thousand Oaks, CA: SAGE Publications.

Huang, H., \& Yongsheng, C. (2011). The relationship between international students' and cross-cultural adaptation and dominant language in Taiwan. International Journal of Humanities and Social Science, 1(7), 137-145.

Huang, Y. (2014). Constructing intercultural communicative competence framework for English learners. Cross-Cultural Communication, 10(1), 97-101.

Lombard, C. A. (2014). Coping with anxiety and rebuilding identity: A psychosynthesis approach to culture shock. Counselling Psychology Quarterly, 27(2), 174-199. https://doi.org/10.1080/09515070.2013.875887

Lukyanova, N., Daneykin, Y., \& Daneikina, N. (2015). Communicative Competence Management Approaches in Higher Education. Procedia - Social and Behavioral Sciences, 214, 565-570. https://doi.org/10.1016/j.sbspro.2015.11.761

Mastor, K. A. J., Sulehan, H., Mustafa, J., Pawanteh, L., Basri, H., Abdullah, S., ... Axel, H. (2011). Personality traits orientation of University Kebangsaan Malaysia (UKM and UKM-University Duisburg-Essen (UDE) engineering students. Procedia-Social and Behavioral Sciences, 8(18), 196-203.

Miles \& Huberman. (2014). Qualitative data analysis: An expanded sourcebook (3rd ed.). Dalam Qualitative data analysis: An expanded sourcebook (2nd ed.).

Muchtar, K., Koswara, I., \& Setiaman, A. (2019). Komunikasi Antar Budaya dalam Perspektif. Jurnal Manajemen Komunikasi, 1(1), 114-124. https://doi.org/10.24198/jmk.v1i1.10064

Mulyana, D., \& Eka, S. B. (2017). Indonesian Students'Cross-cultural Adaptation in Busan, Korea. Jurnal ASPIKOM, 3(2), 144-156.

Nasirudeen, A. M. A., Josephine, K., Adeline, L., Seng, L., \& Ling, H. (2014). Acculturative Stress among Asian International Students in Singapore. Journal of International Students, 4(4). 
Qun, W., Syihabuddin, Mulyati, Y., \& Damaianti, S. V. (2018). Perceiving and dealing with culture shock: The study of Chinese Indonesian-language students. International Journal of Education, 11(1).

Rinehart, R. (2002). Utilitarian or idealist? Frameworks for assessing the study abroad experience, in Grunzweig, W., \& Rinehart, N. (Eds.), Rockin' in Red Square: Critical approaches to international education in the age of cyberculture=. Munster: Lit Verlag.

Safril, S. (2016). Akomodasi Komunikasi dalam Culture Shock Mahasiswa Patani Thailand. Ilmu Dakwah: Academic Journal for Homiletic Studies, 10(2), 331-354. https://doi.org/10.15575/idajhs.v10i2.1080

Safril, Safril. (2016). Akomodasi Komunikasi dalam Culture Shock Mahasiswa Patani Thailand. Ilmu Dakwah: Academic Journal for Homiletic Studies, 10(2), 331-354. https://doi.org/10.15575/idajhs.v10i2.1080

Samovar, S., Larry, A., Richard, E., Porter, P., Edwin, R., \& McDaniel. (2006). Intercultural Communication: A Reader. London: Thomson Wadsworth.

Saylag, R. (2013). Culture Shock an obstacle for EFL learners. 4th World Conference on Psychology, Counselling and Guidance 2013. Procedia - Social and Behavioral Sciences, 114, 533-537.

Sentosa, A. T. (2015). Pola Komunikasi Dalam Proses Interaksi Sosial Di Pondok Pesantren Nurul Islam Samarinda. Jurnal Ilmu Komunikasi, 3(3), 491-503.

Supianoski, W. D. (2012). Cross Cultural interactions Students. Thesis of (Thesis). University of Wisconsin, Whitewater.

Syam, S. (2019). Mengenal Islamisasi: Konflik dan Akomodasi (Kajian Tentang Proses Penyebaran Islam Periode Awal di Nusantara). Al-Hikmah: Jurnal Dakwah Dan Ilmu Komunikasi, 1(2), 76-84. https://doi.org/10.15548/al-hikmah.v1i2.109

Syihabuddin, S. (2014). Merespon konvergensi peradaban dunia melalui bikulturalisme dan internalisasi nilai budaya dalam konteks pendidikan tinggi. Dipresentasikan pada Seminar Nasional Forum Pimpinan Pascasarjana LPTK Indonesia.

White, M., Giles, H., Coupland, J., \& Coupland, N. (1993). Contexts of Accommodation. Language. https://doi.org/10.2307/416913

Yang, M., Webster, B., \& Prosser, M. (2011). Travelling a Thousand Miles: Hongkong Chinese Students' Study Abroad Experience. International Journal of Intercultural Relations, 35(1), 69-78.

Yohana, N., \& Yozani, R. E. (2017). Akomodasi Komunikasi Antarbudaya Imigran Ilegal Asal Afganistan dengan Masyarakat Kota Pekanbaru. Jurnal Komunikasi, 11(2), 95. https://doi.org/10.21107/ilkom.v11i2.3324

Zhang, W. (2014). A brief study on culture shock over overseas students and the solution to new cultural environments. Overseas English, (23), 219-220. 